\title{
DESIGN OF AN INDICATORS SYSTEM FOR THE EVALUATION OF TECHNOLOGICAL INNOVATION IN THE TOURISM DESTINATION OF PUERTO LOPEZ, ECUADOR
}

\author{
Rafael VERA \\ Agricultural Polytechnic University of Manabi Manuel Félix López (ESPAM MFL), \\ Department of Tourism, 130250, Calceta, Manabí, Ecuador, e-mail: jrafaw.4@gmail.com \\ Rodney ALFONSO \\ Agricultural Polytechnic University of Manabi Manuel Félix López (ESPAM MFL), \\ Department of Tourism, 130250, Calceta, Manabí, Ecuador, e-mail: rodney7alfonso@gmail.com \\ Nelson REINOSO* \\ Agricultural Polytechnic University of Manabi Manuel Félix López (ESPAM MFL), \\ Department of Tourism, 130250, Calceta, Manabí, Ecuador, e-mail: nelsongreinoso@gmail.com
}

\begin{abstract}
Citation: Vera R., Alfonso R., \& Reinoso N., (2019). DESIGN OF AN INDICATORS SYSTEM FOR THE EVALUATION OF TECHNOLOGICAL INNOVATION IN THE TOURISM DESTINATION OF PUERTO LOPEZ, ECUADOR. GeoJournal of Tourism and Geosites, 25(2), 623-637. https://doi.org/10.30892/gtg.25227-385
\end{abstract}

\begin{abstract}
The objective of this research was to design indicators for the evaluation of technological innovation (TI) in Puerto López. The methodology used is based on an analysis of the current TI situation and the perspective of the visitors on this issue. The diagnosis reported an incipient technological management by the public institutions and the scarce investment in $\mathrm{R}+\mathrm{D}+\mathrm{i}$. The results provided 19 indicators to evaluate the TI before, during and after the visit, under the dimensions of product, process, organization and marketing that were identified and validated through experts' methods. The indicators show the importance to start working on technological intelligence.
\end{abstract}

Key words: Technological innovation, innovation in tourism, tourism destination.

\section{INTRODUCTION}

Innovation has changed the face of the industry in all sectors of the global economy nowadays. According to Simpson et al., (2006) and Goffin and Mitchell (2017) the positive or negative effects of innovation come out from its orientation. In this sense, not all the "innovative performers" have clearly oriented innovation in the different sectors, therefore the implementation of this factor has not had the expected results. Indeed, it is an indispensable factor for the success and survival of any sort of business in terms of

\footnotetext{
* Corresponding author
} 
getting over competitors today, through the differentiation of their products and services in the market (Hernández, 2013; Rivas, 2006; Azar \& Ciabuschi, 2017; Gault, 2018). For Ponti (2013), Pisano (2015), Dziallas \& Blind (2019) innovating means changing ideas into products, services or strategies to later be valued by a group of target consumers. However, in many countries across the globe, innovation has not been explored in depth due to the lack of knowledge regarding its system. Innovation differs from creativity. Creativity refers to the production of new ideas, new approaches and inventions, whereas innovation is the application of new and creative ideas and the implementation of inventions. From this it follows that people and organizations may be creators without being innovators (Decelle, 2004; Dewangan \& Godse, 2014; Taylor, 2017).

Innovation in tourism must be seen as a permanent, global and dynamic process (Cosma et al., 2014). Innovation system in tourism can be complex as the theoretical underpinning is extensive but scarce in objectivity (Hjalager, 2010). The limited theorizing and empirical investigation of innovative practices by tourism organizations is a considerable weakness (Thomas and Wood, 2014). It means that innovativeness is not only the concept but also the knowing about "what to do" and "how to do it" to transform it into business (Souto, 2015; Mohd et al., 2016). In the entrepreneurial sector, innovativeness can improve the level of incomes, and the number of new jobs. A study run by Ríos y Marroquín (2013) and Kogan et al. (2017) found that a growth in the amount of industry innovation increases the quantity of capital and labor services in the industry. However, for Erspective \& Lusch (2015) TI broadly contributes to enhance the opportunities for innovating services. Clearly, TI is a powerful mechanism for boosting business competitiveness. Since the $90 \mathrm{~s}$, it started to suffer several modifications. Since then, it was no longer a linear model and began evolving into an interactive one which not only considered product and process but the importance of organization and marketing (Redes, 1996; Damanpour et al., 2009). This definition, however, has evolved a lot ever since. In the view of Diaconu (2011) it comprises new or significantly modified products and processes where technological novelty emerges. For instance, the introduction of new technology generates new products or processes in the business. In respect with the aforementioned facts, Alfonso (2013) asserts the following:

TI is the most important power for the change in the production of goods and services. Nowadays, this process is seen as the real and tangible result of technology, which enables innovators to combine technical, financial, commercial and administrative capacities along with the lunching of new and better products or processes to the market. The process of innovating as well as its relationship with society turns out complex, since it not just implies the application of the obtained results from the research at a high level, but also it is the result of entrepreneurial, strategic, organizational and imaginative and decision-making capacities. In this regard (Alfonso, Rodríguez \& Blanco, 2016; Suárez, 2018) assert that the tourism industry has become interested in inserting activities of TI as a competitive strategy for the improvements of results and quality in the service.

Innovativeness in tourism is the combination of applied research (knowledge production), training levels of human capital to enable them to assimilate and communicate that knowledge (knowledge dissemination) and the destinations and companies' capacity to absorb new technologies, therefore, TI itself is an instrument for sustainable growing of companies and destinations, in order to boost the competitiveness in the area where tourism is implemented. Furthermore, In Ecuador, TI is one of the main weaknesses not just in the travel and hospitality industry but in the majority of entrepreneurships. In the public sector, just the MIPRO (Ministry of Industry and Productivity of Ecuador) is working in this field; it has launched the initiative MIPROLab 
to engage university students from all over the country to present innovative proposals that affect positively the economic development. In the PNBV 2013-2017 (National Plan for Good Living of Ecuador) prepared by the National Secretary for Planning and Development of Ecuador [SENPLADES] (2013) innovation is presented as the key mean for the transition from a primary producer- based economy to a knowledge-based economy, and introduces the idea of social and technological innovation as the fundamentals of what is called the Productive Matrix Change. However, the capacity of innovation has not shown any signs of growing in this context as no information inventory exists. Moreover, such structural change must be supported by an easy and understandable policy framework, which leads people to direct their effort to a common goal.

Innovation today is one of the priorities in the tourism agenda at all institutional levels. For the World Tourism Organization [UNWTO] (2018) it is an indispensable tool for management of the tourist activity. However, Ecuador considerably bet on innovation during the past government in order to achieve the goal of changing the productive matrix, for this purpose, the current Government Secretariat for Higher Education, Science and Technology ([SENESCYT] Government Secretariat of Science and Technology [SENACYT] by then) in 2015 promoted great support for innovative ventures and promoted proposals for innovation in various fronts of the economy and invested in the global training of human talent. This year marked important advances for this phenomenon, such as the appearance of Innopolis (Fair of innovation projects) managed by the university YACHAY TECH, the same that has led to innovations, which have been more linked to the development of technologies and robotics, with a low impact on tourism activity. Currently, SENESCYT continues to support innovation projects through its web portal "Banco de Ideas" that promotes calls for proposals. However, so far there have been no emblematic innovative projects directly linked to tourism activity.

Further, it seems that the importance of innovative decisions in businesses or public planning is still somewhat underestimated. Nontheless, in some tourist SMEs (Small and Medium Sized Enterprises) - the predominant number of establishments in Ecuador in this sector- incremental innovation without $\mathrm{R}+\mathrm{D}$ is being seen as a tool of growth, in contrast, radical innovation is a quasi-non-explored field.

On the other hand, when it comes to the reality of tourism in Ecuador, the lack of innovative ideas in the academic, social, political, organizational, technological, cultural, entrepreneurial, environmental, and infrastructural dimensions is easily visible. Indeed, as a result of the misconception of the relationship between TI \& ICT (Information and Communication Technology) because of its versatility to be implemented in any of those dimensions, has made people term any change as innovation. Despite the existence of incipient guidelines to steer the course of innovation in the country, no cantons in the province of Manabí have implemented a successful innovative strategy to attract visitors; actually, in their rural localities tourism is not observed as an alternative for local development yet, and lacks of technological infraestructure. For that reason, it is important to evaluate the current and potential application of innovative ideas to foster the activity in those areas by conceiving TI under the lens of systematization and defining procedures and tools that facilitate its implemantation and evaluation.

Moreover, Manabí is is now experiencing an infrastructural, social and economic recovery from a devastating event. On April 16, 2016 an earthquake of magnitude 7.8 on the Richter scale shaked the northwest coast of Ecuador, the event caused great losses to the tourism sector (Garcia et al., 2018), the total cost of reconstruction is estimated at 3344 MM USD, the sector hotel, food and entertainment in the province of Manabí was destroyed by $80 \%$. In the tourism subsector, a total reconstruction cost of 97 million USD 
(9.4\% of the productive sector) was estimated, which includes (Reinoso et al., 2019) the cost of the immediate response to the event, the reconstruction of assets and the lost flows. In consecuence, the tourism activity in Manabí after the earthquake, must be reformulated, so it requires the new reality, it is necessary to analyse the (...) problems and their causes that motivate the stagnation in tourism management, learn the needs and the requirements of tourism service providers, redesigning new products aimed at motivating demand and implementing strategies that motivate the reactivation of tourist activity through the improvement of tourist offers, and communication (marketing) of the destination (Garcia, et al., 2016). At this time, it is necessary for Puerto López to take care of innovation to keep tourists motivated to visit the destination.

With this in mind, it is time to start planning from a renewable perspective that greatly affect in the face of tourism in the medium to long term. For this reason, it is viable to state the idea that the evaluation of the technological innovation will allow planners to establish better conditions to improve the tourist supply in the territory. The evaluation must be performed by the application of an indicators system. According to Alfaro \& Gómez (2016) for the construction of any indicators system, the need to establish the characteristics of the incoming information is key so that the data provided by the different official information sources are related to the dimensions of the previously selected evaluation. In the end, TI in tourism has been studied in Ecuador just in the hotel area, so it is evident that it is still an emerging issue in tourism destinations, since instruments for the evaluation in this field are dispersed, complex and difficult to define. Therefore, this research embodies the design of an indicators system for the evaluation of TI in Puerto López from the destination perspective as a pioneering reference.

\section{MATERIALS AND METHODS}

This qualitative study was based on an analytic-synthetic approach. The revision of previews methodologies for the definition of indicators was considered as a starting point for the research. The methodology for the study was structured in three phases (Figure 1).

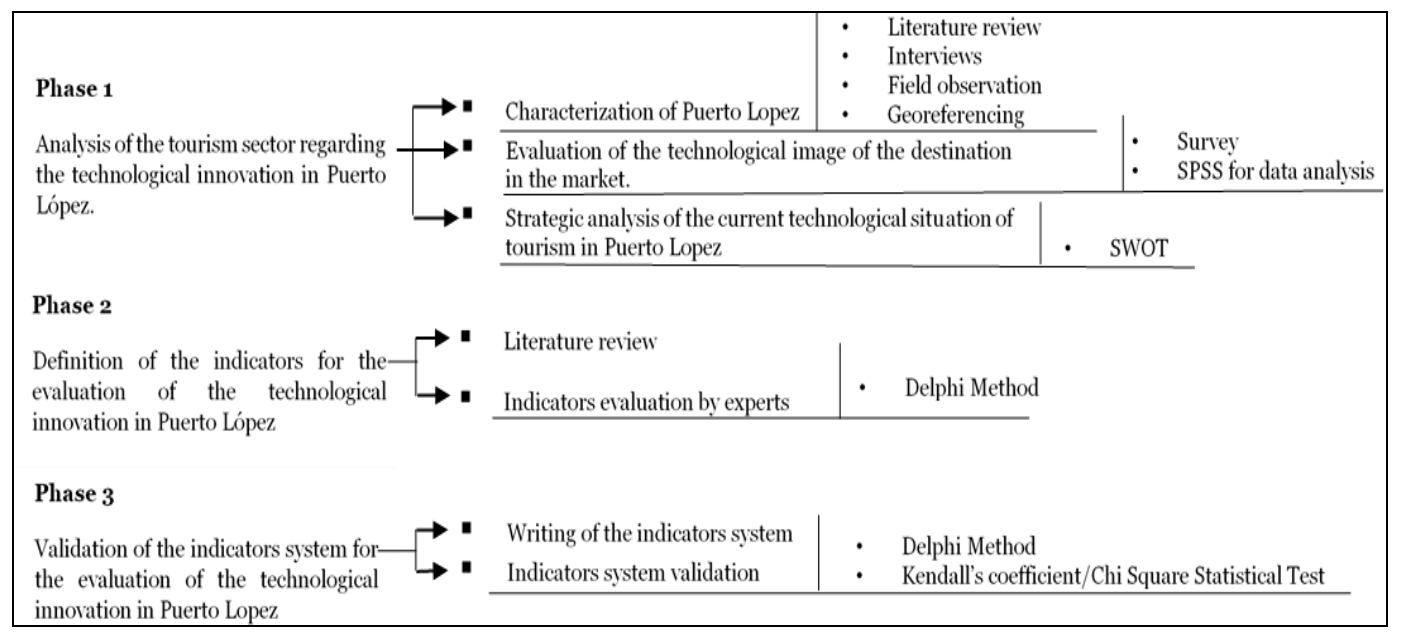

Figure 1. Procedure for the research development

In the first phase, scientific observation with field visits were performed to raise information for the analysis of the current situation regarding TI in tourism in Puerto Lopez. Interviews to officials of the local government and departments linked to tourism 
were fundamental techniques to get information as well as the survey run over visitors to the canton to learn about their perception of the destination on TI. Georeferencing of the tourist areas in the destination was done, and the participative tourist strategic analysis with the application of the SWOT matrix provided the main problem and the strategic solution on this issue. For the collection of data, the sampling procedure was defined, information collection instruments were designed, quantitative techniques were applied and the statistical package SPSS version 29 was used. To determine the sample size, the methodology proposed by Alatorre \& Pérez (2011) was used but following a statistical criterion and assuming an infinite population. The variability of the population is estimated at $50 \%(\mathrm{p}=\mathrm{q}=0.5)$, a widely used value in social research (Meiriño et al., 2016) 191 valid surveys were collected, representing a sampling error of $7.2 \%$ with a confidence level of $95 \%$. In the second phase, the literature review for the identification of indicators allowed to get a preliminary list of possible and / or potential ones to address each of the adjacent problems and policy issues of the destination.

Those that best fitted the needs of the territory were considered in the context of the potential and existing technological reality. The Manual of Bogota prepared by Jaramillo, Lugones \& Salazar (2001) was considered as a key tool for the identification of innovation indicators in relation to the measurement dimension and the types of indicators, this manual is an adaptation of the Oslo Manual (RICyT, 1997), to the Latin American context; this, in turn, was compared to its latest edition (OECD, 2005).

However, none of these manuals presents an approach - albeit partially - touristy but fully entrepreneurial, so the indicators proposed in the Operational Manual for the Configuration of Smart Tourism Destination (STD) by the Agencia Valenciana del Turisme [Invat.Tur], (2015) of which those that are directly related to technological innovation were extracted to merge with the sectors, dimensions, and stages of the potential evaluation. Finally, the third phase consisted of the writing of indicators for the evaluation of TI which were developed from their validation through the application of the experts' method, analyzing their criteria by the Chi-square statistical test to verify if there is a coincidental coincidence in the criteria issued by the experts. Within this, a value of the Kendall concordance coefficient (W) was obtained. The mathematical expression for its calculation is (Badii et al., 2014; Márquez \& Márquez, 2018):

$$
W=\frac{s}{\frac{1}{12} k^{2}\left(N^{3}-N\right)}
$$

Where: $W=$ Kendall concordance coefficient; $S=$ Standard deviation; $N=$ Number of criteria; $k=$ Number of experts.

\section{RESULTS DISCUSSIONS}

\section{Tourist zoning of Puerto López}

According to the Spatial and Territorial Development Plan, Municipality of Puerto López (PDOT) prepared by the Municipality of Puerto López [GAD Puerto López] (2015), this is one of the 22 cantons of the province of Manabí, located in the southwestern part of the province, strategically crossed by the Spondylus Route (road artery E-15), in the Machalilla National Park (MNP) which is a protected area that covers about $60 \%$ of its territory, the canton has an area of $429.36 \mathrm{~km}^{2}$, it borders on the north and east with the canton of Jipijapa, to the south with the province of Santa Elena and to the west with the Pacific Ocean, it is between the coordinates $01^{\circ} 10$ 'and $01^{\circ} 40^{\prime}$ of south latitude and 
between $80^{\circ} 25$ 'and $80^{\circ} 52^{\prime}$ of Western longitude. The georeferencing of the zones of the canton shows the areas where tourism affects directly and those in which it does not but belong to the MNP and therefore integrates a protected area (Figure 2).

In Figure 2, the territory of Puerto López is divided in three main zones:

1. Tourist use zone

2. Tourist operations zone (urban zone)

3. Zone of the Machalilla National Park (Protected area)

The tourist zone of the canton is constituted by the most visited sites; those are the naturally and culturally rich. Among the sites of the tourist zone are:

- Agua Blanca Community

- Los Frailes beach

- And the beach of Puerto López town center.

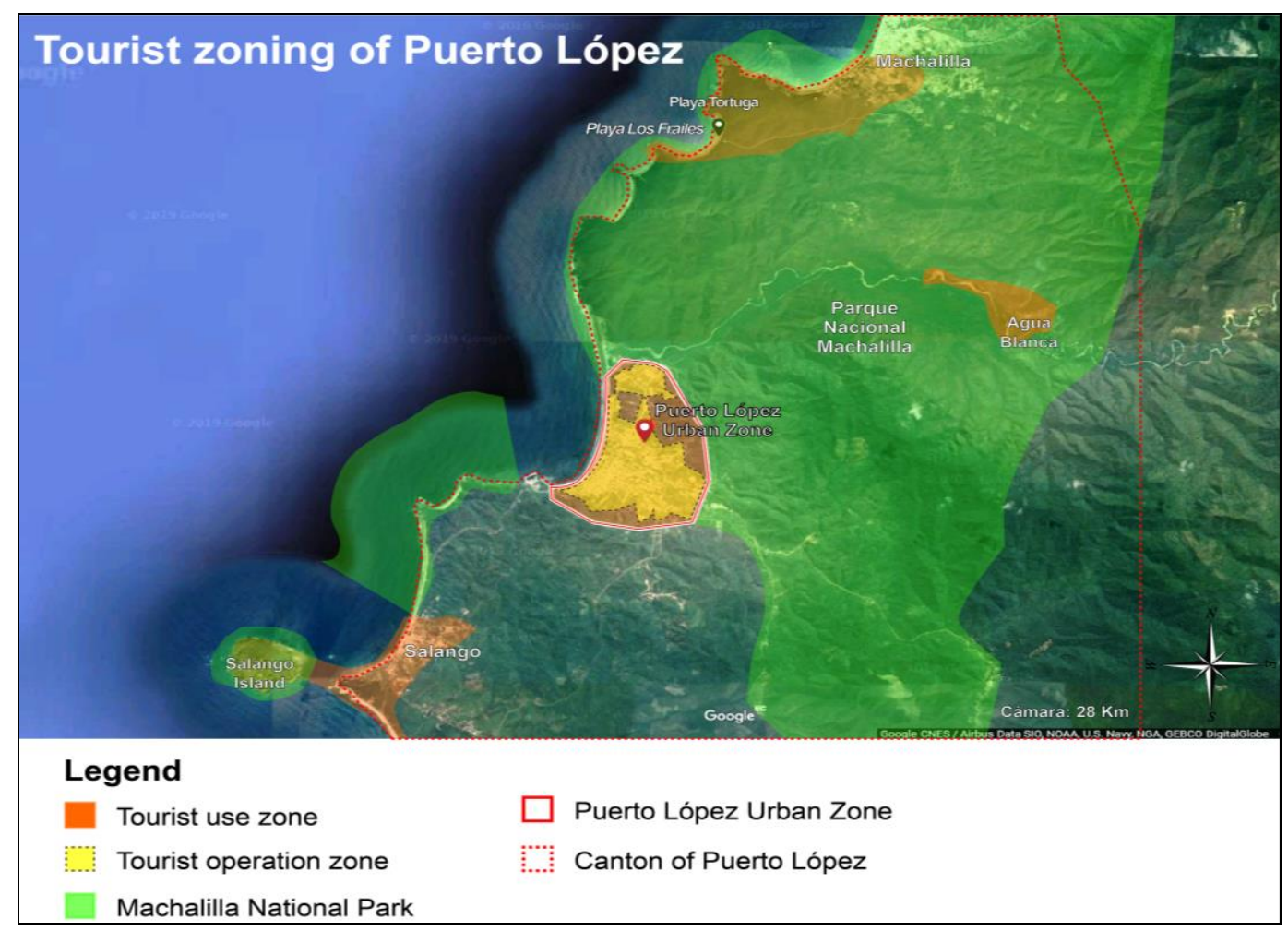

Figure 2. Different tourism affected areas (Source: Processing on topographic map Google Earth)

The Agua Blanca Community is located in the MNP, in the parish of Machalilla. This site receives more than 16.00o visitors every year (Agua Blanca Comunidad Ancestral, n.d.). It has plenty of cultural and natural supply. Here, visitors can see archaeological remains of the Manteños Tribe (500-1532 A.C.). This activity is complemented by the existence of a hot spring lagoon where people can have a thermal water bath and wildlife observation. Likewise, Los Frailes beach is an important site located within the MNP where most of the visitors to Puerto López come. It is one of the most visited protected beaches in Ecuador which is surrounded by dry forest and lacks any human construction on the seaside to keep it in a natural state. 
The tourist use zone in town center is the place where public access to the beach at any time and tourist facilities such as accommodation, restaurants as well as tour operators' service merge, since the tourist operations zone is in the same area. Another relevant tourist site in Puerto López is Salango, this little town runs activities like boat trips, snorkeling by the Salango Island, and sea life observation. Despite the fact that it is not the most visited site in the canton, it is a place of remarkable tourism importance due to its natural wealth complemented with an archaeological museum. MNP is the biggest zone drawn in the map. This protected area owns a wide variety of flora and fauna.

Due to the fact that it covers the larger part of the territory of Puerto López, environmental management is strictly regulated by the Environmental Ministry of Ecuador (MAE), however, as a result of its various forms of production, there are other ministerial posts which directly or indirectly intervene in the management of the territory such as the Ministry of Tourism (MINTUR) and the Ministry of Agriculture, Livestock (MAG), Aquaculture and Fishing (MAP) among others governmental offices. Despite all the efforts, for the GAD Puerto López (2015) there are natural resources that have been degraded by the intervention of the human being and its causes such as: deforestation and pollution, among them the deterioration of the flora and fauna as well as those of the rivers' basins.

\section{Characterization of Puerto López}

Its population is of 20,451 inhabitants of whom the predominant number reaches a secondary level, followed by elementary level of schooling, most of them are involved in the tertiary sector, but not directly linked to tourism but to the administrative and teaching functions (INEC, 2010). Puerto López is politically made up of three parishes (Machalilla, Salango and Puerto López [urban area]). Within these three parishes there are 31 villages of which 4 are communes (Agua Blanca, El Pital, Las Tunas and Ayampe) that have their own organizations from which Agua Blanca is the most visited. In the northern part of the canton the climate oscillates between 26 and $24^{\circ} \mathrm{C}$, in the southern part between 22 a $24^{\circ} \mathrm{C}$; with an annual precipitation between $\mathrm{o}$ and $1500 \mathrm{~mm}$. It has several rivers that flow into the sea, excelling as the main basin, the Ayampe River, which shares its route with the canton Jipijapa. Fishing represents the most important source of income for the canton in general and the parishes of Machalilla and Salango - with the exception of the urban parish of Puerto López. The Machalilla parish, is the least benefited by tourism. This reality contrasts with the statistics of the economic active population (EAP) which represents $46.53 \%$ of the population of the canton (INEC, 2010) where the majority of them work in the tourism field. In addition to these activities, there are other sources of income such as agriculture, livestock, forestry and poultry farming, especially in the rural area, however, their low level of production plays down their importance in the local economy (GAD Puerto López, 2015).

The strategic location of Puerto López facilitates the access to and from it. Its roads are of second order. The road infrastructure inside the town is deteriorated, which makes transportation and internal mobilization somewhat difficult. One of the most important streets is the waterfront one, which was rebuilt in the last five years and now represents a nice urban landscape unlike the rest of the city. In contrast, access to rural areas is limited. The canton has 44 educational establishments (primary and secondary level), none of them at university level, has three health centers (two sub-centers and one community clinic).

The majority of the population does not have access to basic services.Within the framework of the tourist superstructure, the MAE is the institution that regulates any type of activity, including tourism. MINTUR currently does not have a tourism office in the canton, so the task of promotion and dissemination is carried out by the tourism department of the GAD of the canton, while the community sector assumes its touristic role. There is an association of hoteliers, and also restaurants and operators, however, their 
objective is to enhance the achievement of operating permits, so currently they are not leading any project that promotes TI in tourism from the private sector. In addition, there is a lack of interest of these key actors for inter-institutional and intersectoral cooperation and coordinated work for the management of tourism in the territory. Tourism dynamics in the canton of Puerto López is consistent, with a greater influx of visitors between the months of June to September, largely due to the observation season of humpback whales. Tourist facilities consist of 71 accommodation establishments, 25 food and beverage establishments, 32 travel agencies and a tourist transport agency. One of the most outstanding weaknesses that tourism in Puerto Lopez currently faces today is the lack of a strategic plan to direct the processes of tourism management in the territory, followed by administrative instability as department directors are normally changed when a new major is elected.

This has caused the lack of firm projects, which promote constant development; as a result of this, the shift managers have mainly directed the management of this activity to promotion especially in national and international fairs, with limited presence in social networks. The results of this management approach affect tourism in the territory, since conflicts among public institutions in charge of the tourism management exist, added to limitations in infrastructure. Further, another of the serious problems affecting tourism development, especially at the business level, is the activity of "hooking"which leaves little profit margin to operators, preventing them from improving their services.

\section{DATA ANALYSIS}

Important information concerning innovation was analyzed to construct the questionnaire for the survey. In this regard, the criteria stated in the White Paper for STD (Blanco, 2015) and the "Tourism destinations report: building the future" (López-de-Ávila et al., 2015) were considered to build the questions. Relying on the manuals revised, the technological interaction between the tourists and the destination must be present in the three stages that make up the process of a visit, they are:

$\checkmark$ Before the visit: the raising of awareness of what the destination has regarding its products and services, and the way to provide the right and quick response to the potential tourists' questions for them to make the right decisions on time.

$\checkmark$ During the visit: technological facilities to enhance the access to information for visitors while in the destination, is an indispensable feature of a STD.

$\checkmark$ After the visit: Public departments must be interested in the tourists' perceptions of the destination, so that it is easy for the tourism managers to learn about the customer's satisfaction and therefore improve the products and services to overcome visitors' complaints.

Set forth below are the results: This analysis of data collected is developed by grouping the qualitative and quantitative questions applied to visitors into two parts.

The first analysis consisting of qualitative yes or no questions, showed that the frequency of people who had informed on the web before the visit is $68.9 \%$ and $63.4 \%$ of the respondents reported that there are no official virtual tourist information channels where they can ask questions about tourism products and services and get answers in a short time. With regard to the existence of private virtual channels that resolve the concerns of tourists before the trip, $74.3 \%$ responded affirmatively. In contrast to the public sector, Puerto Lopez companies are interested in providing quick and timely information to both real and potential tourists through virtual channels. 86.9\% reported that there are no technological applications aimed to facilitate the access to information and services in the destination, so that it makes easier for visitors to better interact with the destination, this percentage in turn represents the total of the questions answered. 
86.4\% of tourists reported that in Puerto López there are no QR modules that contain information on sites and $59.7 \%$ of them determined that there are no rental technology devices in the tourist kiosk. In respect with public areas with free Wi-Fi points installed and managed by the official institutions responsible for managing the territory 74.3\% of the respondents reported no existence. $66.5 \%$ of the visitors reported that they have not received any promotional information about Puerto López after their visit, this shows a weak tracking of the tourist for their loyalty to the destination.

In the second part, the rating of the information about the destination available on the web is at an average of $3.83( \pm 1.67)$ under the regular parameter. The official use of social networks for tourism promotion and dissemination has a similar average of 3.03 ( \pm 1.79); the use of ICT for the management of products in the territory shows an average of $2.55( \pm 1.36)$ under the bad parameter, in a similar way, the technological infrastructure of Puerto López is at an average of $2.02( \pm 1.16)$ followed of the use of the TIC for the information of the experiences of the tourists after the visit, with an average of 2.0 ( \pm o.98). The result of the surveys shows an incipient technological management on the part of the public institutions in charge of the tourist activity. The current perception of the visitor of Puerto López, shows the urgent need to implement a technological infrastructure to boost the interaction of the visitor with the destination, before, during and after his visit, through technological tools and web channels such as social networks.

\section{SWOT}

This part of the study was participative. It contributed to the analysis of the current situation of the technological innovation in Puerto López, and provided guidelines for the design of the indicators as the main problems related to this field are stated. For the achievement of this step, experts of the different institutions (MAE- GAD cantonal), academics (ESPAM MFL, Department of Tourism) and entrepreneurs (travel agents, restaurants, transportation and hotels) involved in tourism in the territory took part in the preparation of the analysis. All of the information stated and selected by the participants were compared to the information available in the PDOT of Puerto López and by means of other sources like interviews and direct observation before analyzing and rating them in the SWOT matrix. From the preparatory stage, the following variables were selected and prioritized in accordance to their importance:

\section{Strengths}

1. Territory with a wide variety of natural and cultural resources of national heritage value.

2. Potentiality of the territory for the implementation of technological infrastructure.

3. Destination of tourist interest positioned in the domestic and international market.

4. Strategic location (on the Spondylus route, near two international airports [Manta and Guayaquil])

5. Priority area located within the MNP (protected area).

\section{Weaknesses}

1. Lack of a tourism strategic plan (lack of planning related to technological innovation).

2. Deficient use of ICT for tourism management in the territory.

3. Deficient technological infrastructure.

4. Scarce investment in $\mathrm{R}+\mathrm{D}+\mathrm{i}$.

5. Limited cantonal budget for tourism management.

\section{Opportunities}

1. Public policies to boost innovation

2. Global access to technology transfer.

3. Economic capacity of the central government to develop $\mathrm{R}+\mathrm{D}+\mathrm{i}$ projects. 
4. Presence of institutions for advice in the development of projects (universities, SENPLADES, MAE, MINTUR, etc.)

5. World tourism trend towards the STD.

\section{Threats}

1. Potential competitors with similar natural and / or cultural characteristics.

2. Limitations in the application and monitoring of $\mathrm{R}+\mathrm{D}+\mathrm{i}$ projects.

3. Administrative instability for tourism management in the governmental secretariats.

4. Eventual policies of economic austerity due to crisis in the country.

5. Environmental degradation (flooding, earthquake, landslide).

After rating all the variables in the matrix, it reported that the main problem that the canton has is the scarce investment in $\mathrm{R}+\mathrm{D}+\mathrm{i}$, but the most outstanding opportunity is the existence of public policies to boost innovation.

\section{Indicators system for the TI evaluation in Puerto López}

A model named as Star Model for the management of TI was designed with the integration of all the sectors (public, private and community), dimensions (product, process, organization \& marketing) and stages (before, during \& after the visit) which affect it in order to facilitate its interpretation and reduce the visual impact (Figure 3).

\section{Public}

Before the

During the
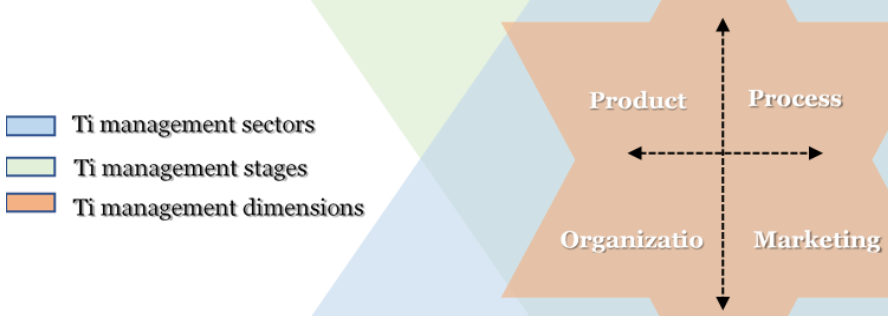

Private

Community

After the

Figure 3. Star Model for the management of TI (Source: Self-reported information)

The types of indicators are established according to the classification established in the Bogota Manual which are of impact (I), expenses (E) and dissemination (D). In the matrix (Table 1), it is marked on two important axes (sector and dimension) on which technological innovation intervenes or positively impacts. However, it is important to clarify that by indicating in the quadrant responsibility for the execution of this activity does not completely exclude the other sectors when it is applicable. It is suggested through the relationship with the indicators to establish the minimum requirements for a positive result 
Design of an Indicators System for the Evaluation of Technological

Innovation in the Tourism Destination of Puerto Lopez, Ecuador

in the evaluation of technological innovation. The preliminary list of indicators, was submitted to experts for analysis and subsequent validation. Based on the validation of the indicators, by the experts, 19 indicators were determined with their code and measurement criteria.

Table 1. Indicators system for the evaluation of the TI in Puerto López before the visit

\begin{tabular}{|c|c|c|c|c|c|c|c|c|c|}
\hline \multicolumn{10}{|c|}{ Before the visit } \\
\hline \multirow{2}{*}{ INDICATOR } & \multirow{2}{*}{ CODE } & \multirow{2}{*}{ CRITERION } & \multicolumn{7}{|c|}{\begin{tabular}{|l|l|} 
SECTOR DIMENSION \\
\end{tabular}} \\
\hline & & & $\mathbf{G}$ & $\mathbf{P}$ & $\mathbf{C}$ & $\mathbf{p}$ & pp & $\mathbf{0}$ & $\mathbf{m}$ \\
\hline $\begin{array}{l}\text { Certifications and/or } \\
\text { recognitions on products } \\
\text { and / or processes } \\
\text { related to technological } \\
\text { innovation }\end{array}$ & INoO1 & $\begin{array}{l}\text { Number of recognitions and / or } \\
\text { certifications achieved in the last } 5 \\
\text { years that reflect the adequate } \\
\text { management of technological } \\
\text { innovation in the territory }\end{array}$ & $\mathrm{x}$ & $\mathrm{x}$ & $\mathrm{x}$ & $\mathrm{x}$ & $\mathrm{x}$ & $\mathrm{x}$ & $\mathrm{x}$ \\
\hline $\begin{array}{l}\text { Agreements Government- } \\
\text { Company-University for the } \\
\text { development of technological } \\
\text { innovation for tourism }\end{array}$ & INoO2 & $\begin{array}{l}\text { Number of agreements for the } \\
\text { evaluation of the cooperation } \\
\text { between these key actors for the } \\
\text { promotion of innovation }\end{array}$ & $\mathrm{x}$ & $\mathrm{x}$ & & $\mathrm{x}$ & $\mathrm{x}$ & $\mathrm{x}$ & $\mathrm{x}$ \\
\hline $\begin{array}{l}\text { External investment in } \\
\mathrm{R}+\mathrm{D}\end{array}$ & ENoO3 & $\begin{array}{l}\text { Number of R \& D incoming projects } \\
\text { managed by NGOs, universities or } \\
\text { government agencies which are not } \\
\text { directly linked to the tourism } \\
\text { innovation management in the territory }\end{array}$ & & & & $\mathrm{x}$ & $\mathrm{x}$ & $\mathrm{x}$ & $\mathrm{x}$ \\
\hline Technological innovations & INoO4 & $\begin{array}{l}\text { Number of technological innovations } \\
\text { run in the territory in the last } 5 \text { years }\end{array}$ & $\mathrm{x}$ & $\mathrm{x}$ & $\mathrm{x}$ & $\mathrm{x}$ & $\mathrm{x}$ & $\mathrm{x}$ & $\mathrm{x}$ \\
\hline $\begin{array}{l}\text { Programs of control and } \\
\text { assurance of quality } \\
\text { through technology }\end{array}$ & ENoO5 & $\begin{array}{l}\text { Number of programs led by public, } \\
\text { private or community companies on } \\
\text { quality control and assurance programs }\end{array}$ & $\mathrm{x}$ & $\mathrm{x}$ & $\mathrm{x}$ & $\mathrm{x}$ & $\mathrm{x}$ & $\mathrm{x}$ & \\
\hline $\begin{array}{l}\text { Updating of social } \\
\text { networks }\end{array}$ & DFoo6 & $\begin{array}{l}\text { Frequency of updating information in } \\
\text { social networks of official use }\end{array}$ & $\mathrm{x}$ & $\mathrm{x}$ & $\mathrm{x}$ & $\mathrm{x}$ & $\mathrm{x}$ & $\mathrm{x}$ & $\mathrm{X}$ \\
\hline $\begin{array}{l}\text { Programs / projects aimed } \\
\text { at promoting ITA }\end{array}$ & ENoO7 & $\begin{array}{l}\text { Number of registered programs or } \\
\text { projects linked to technological } \\
\text { innovation }\end{array}$ & $\mathrm{x}$ & $\mathrm{x}$ & $\mathrm{x}$ & $\mathrm{x}$ & $\mathrm{x}$ & $\mathrm{x}$ & $\mathrm{x}$ \\
\hline Tourist website & DNoo8 & $\begin{array}{l}\text { Number of attractive, simple and fast } \\
\text { web page/s, adapted to all devices } \\
\text { that encourage interaction and co- } \\
\text { creation processes with the } \\
\text { possibility of booking Tourist chat. } \\
\text { Virtual call center: Skype, example. } \\
\text { Virtual tourist office: Facebook, example }\end{array}$ & $\mathrm{x}$ & $\mathrm{x}$ & $\mathrm{x}$ & & $\mathrm{x}$ & $\mathrm{x}$ & $\mathrm{x}$ \\
\hline $\begin{array}{l}\text { Technological training } \\
\text { associated with new and } \\
\text { improved processes and } \\
\text { products }\end{array}$ & EPoo9 & $\begin{array}{l}\text { Percentage of investment by } \\
\text { companies in human capital training } \\
\text { for the incorporation of new } \\
\text { technologies }\end{array}$ & $\mathrm{x}$ & $\mathrm{x}$ & $\mathrm{x}$ & & $\mathrm{x}$ & $\mathrm{x}$ & \\
\hline $\begin{array}{l}\text { Use of ICT by tourism } \\
\text { companies }\end{array}$ & IPO10 & $\begin{array}{l}\text { Percentage of companies that manage } \\
\text { their tourism products through ICT }\end{array}$ & & $\mathrm{x}$ & & & $\mathrm{x}$ & & $\mathrm{x}$ \\
\hline
\end{tabular}

It also indicates the sectors in which the indicators intervene in the different stages, as well as their respective dimensions. At the suggestion of experts, another indicator related to the importance of evaluation of technology management on the Triple Helix model (government- business-university) proposed by Castillo et al. (2014) was added to the list. Some of the indicators identified in the previous section were separated from this study due to their scarce relationship with the reality observed in the study area. The indicators which integrate the system were finally framed within the three stages of the visit 
and separated according to them for a better interpretation. For each table, in the code column, the first letter shows the type of indicator $(\mathrm{I}=$ impact, $\mathrm{E}=$ expenditure, $\mathrm{D}=$ Dissemination), the second letter indicates the proposed measure of the indicator $(\mathrm{N}=$ number; $\mathrm{G}=$ degree, $\mathrm{F}=$ frequency and $\mathrm{P}=$ percentage). In the quadrants corresponding to the sector, they are classified as $\mathrm{G}=$ public sector, $\mathrm{P}=$ private sector, and $\mathrm{C}=$ community sector. With respect to the evaluation of dimension, they are $\mathrm{p}=$ product, $\mathrm{pp}=$ process, $\mathrm{o}=$ organization, and $\mathrm{m}=$ marketing. The indicators stated in Table 1 show an overall view of what the canton Puerto Lopez must consider to start planning to improve the innovation in technology oriented to improve the processes of getting in touch with the destination before the visit. Indeed, the indicators selected by experts are in coherence with the current situation of the territory and do not represent excessive costs.

The indicators written in table 2, clearly stated the criteria of experts on the strategic technological things to improve the experience of the tourists while in the destination, it shows the importance of the private and community sectors participation for the implementation of a better technological infrastructure in the canton.

Table 2. Indicators system for the evaluation of the TI in Puerto López during the visit

\begin{tabular}{|c|c|c|c|c|c|c|c|c|c|}
\hline \multicolumn{10}{|c|}{ During the visit } \\
\hline \multirow{2}{*}{ INDICATOR } & \multirow{2}{*}{ CODE } & \multirow{2}{*}{ CRITERION } & \multicolumn{7}{|c|}{\begin{tabular}{|l|l|} 
SECTOR DIMENSION \\
\end{tabular}} \\
\hline & & & G & $\mathbf{P}$ & $\mathbf{C}$ & $\mathbf{p}$ & $\mathbf{p p}$ & о & $\mathbf{m}$ \\
\hline Mobile applications developed & INo11 & $\begin{array}{l}\text { Number of mobile Apps } \\
\text { designed to facilitate the } \\
\text { interaction of the tourist with } \\
\text { the destination for decision } \\
\text { making within it. }\end{array}$ & $x$ & $\mathrm{x}$ & $\mathrm{x}$ & $\mathrm{x}$ & $\mathrm{x}$ & & \\
\hline $\begin{array}{l}\text { Quality connectivity to the } \\
\text { network of tourist companies of } \\
\text { the destination with latency }\end{array}$ & IGo12 & $\begin{array}{l}\text { Degree of sufficient bandwidth } \\
\text { and limited latency to offer } \\
\text { agility in the service }\end{array}$ & & $\mathrm{x}$ & $\mathrm{x}$ & $\mathrm{x}$ & $\mathrm{x}$ & & \\
\hline $\begin{array}{l}\text { Wi-free network with QoS } \\
\text { guaranteed in public places of } \\
\text { tourist affluence (parks, } \\
\text { museums, piers, etc.) as well as in } \\
\text { tourist companies (hotels, } \\
\text { restaurants, shops, etc.) }\end{array}$ & INo13 & $\begin{array}{l}\text { Number of KBPS of available } \\
\text { flow per terminal when the } \\
\text { area is at } 20 \% \text { of its capacity } \\
\text { of regular users }\end{array}$ & $\mathrm{x}$ & & & $\mathrm{x}$ & & & \\
\hline $\begin{array}{l}\text { Software created and licensed } \\
\text { for the tourist and hotel sector }\end{array}$ & DGo14 & $\begin{array}{l}\text { Degree of the automation of } \\
\text { visitor information }\end{array}$ & $\mathrm{x}$ & & & & $\mathrm{x}$ & $\mathrm{x}$ & \\
\hline $\begin{array}{l}\text { Existence of NFC, QR, } \\
\text { RFID, etc. }\end{array}$ & DNo15 & $\begin{array}{l}\text { Number of interpretive panels } \\
\text { and promotional material } \\
\text { with NFC, QR, RFID or others }\end{array}$ & $\mathrm{x}$ & & & $\mathrm{x}$ & $\mathrm{x}$ & $\mathrm{x}$ & \\
\hline
\end{tabular}

Table 3 shows the indicators that must be considered to enhance the keeping-intouch with the visitors, start working on technological intelligence to virtually know them, learn about their perceptions and keep them loyal to the destination to overcome the limitations that affect the image of the destination. The experts' opinions were analyzed by means of a Chi-Square statistical test, to verify if there is a coincidental coincidence in the criteria issued by the experts. Within this, a value of the coefficient of agreement of Kendall was obtained ( $\mathrm{W}=0.991)$. It was obtained as a result of the Chi-square test $124.84>3.94 \rightarrow$ Therefore, there is no accidental coincidence among the experts, which leads to the conclusion that there is strong consistency among them. The result of the application of the evaluation instrument (Kendall method with Chi-square statistical test) reported that the vast majority of the answers in the evaluations by the experts are located within the classification: strongly agree or agree and that of the proposed indicators 
Design of an Indicators System for the Evaluation of Technological

Innovation in the Tourism Destination of Puerto Lopez, Ecuador

system which stand out for the evaluation of the Ti in Puerto Lopez are, Certifications / recognitions on products and / or processes related to technological innovation, Technological innovations with R \& D, Innovative tourism activities (ITA), Programs / projects aimed at promoting ITA, Use of ICT by tourism companies and Open data (OD).

Table 3. Indicators system for the evaluation of the Ti in Puerto López after the visit

\begin{tabular}{|c|c|c|c|c|c|c|c|c|c|}
\hline \multicolumn{10}{|c|}{ After the visit } \\
\hline \multirow{2}{*}{ INDICATOR } & \multirow{2}{*}{ CODE } & \multirow{2}{*}{ CRITERION } & \multicolumn{7}{|c|}{\begin{tabular}{|l|l|} 
SECTOR & DIMENTION
\end{tabular}} \\
\hline & & & G & $\mathbf{P}$ & $\mathbf{C}$ & $\mathbf{p}$ & pp & $\mathbf{0}$ & $\mathbf{m}$ \\
\hline $\begin{array}{l}\text { Characterization of } \\
\text { the tourist demand } \\
\text { satisfaction }\end{array}$ & IFo16 & $\begin{array}{l}\text { Frequency of online surveys, account of } \\
\text { experiences, opinions, complaints and / } \\
\text { or suggestions }\end{array}$ & $\mathrm{x}$ & $\mathrm{x}$ & $\mathrm{x}$ & & $\mathrm{x}$ & $\mathrm{x}$ & \\
\hline Open data (OD) & DGo17 & $\begin{array}{l}\text { Degree of Information on the platform } \\
\text { shared by companies, organizations and } \\
\text { institutions to facilitate R \& D processes }\end{array}$ & $\mathrm{x}$ & $\mathrm{x}$ & $\mathrm{x}$ & $\mathrm{x}$ & $\mathrm{x}$ & $\mathrm{x}$ & $\mathrm{x}$ \\
\hline $\begin{array}{l}\text { Brand and media } \\
\text { monitoring }\end{array}$ & IGo18 & $\begin{array}{l}\text { Degree of technological surveillance to } \\
\text { analyze what is said of the destination in } \\
\text { social networks, frequency of use, what } \\
\text { is the profile of our digital visitor \& the } \\
\text { study of competitors }\end{array}$ & $\mathrm{x}$ & $\mathrm{x}$ & $\mathrm{x}$ & & $\mathrm{x}$ & & $\mathrm{x}$ \\
\hline $\begin{array}{l}\text { CRM (Gestión de la } \\
\text { relación con el cliente) } \\
\text { yestrategias demarketing } \\
\text { por correo electrónico }\end{array}$ & DNo19 & $\begin{array}{l}\text { Number of promotions, last minute } \\
\text { offers with the profile of the visitor, } \\
\text { aimed at inspiring and loyalty }\end{array}$ & & $\mathrm{x}$ & & & $\mathrm{x}$ & & $\mathrm{x}$ \\
\hline
\end{tabular}

Table 4. Result of the application of the Kendall's method

\begin{tabular}{|c|l|}
\hline Experts (E) & 7 \\
\hline Number of indicators (N) & 19 \\
\hline$\sum \mathrm{S}^{2}$ & 27671.79 \\
\hline $\mathrm{N}^{3}-\mathrm{N}$ & 6840 \\
\hline $\mathrm{E}^{2}$ & 49 \\
\hline $\mathrm{E}^{2 *}\left(\mathrm{~N}^{3}-\mathrm{N}\right)$ & 335160 \\
\hline $12{ }^{*} \mathrm{~S}^{2}$ & 332061.48 \\
\hline $\mathrm{W}$ & 0.991 \\
\hline $\mathrm{X}^{2}$ & $\mathbf{1 2 4 . 8 4}$ \\
\hline $\mathrm{X}^{2}{ }_{0,05 ; 18}$ & $\mathbf{2 8 . 8 6}$ \\
\hline
\end{tabular}

\section{CONCLUSION}

According to the importance attributed to the elements of innovation and technology in the literature reviewed for the recognition of a tourism destination, the canton of Puerto López reflects limitations in terms of its technological infrastructure, as well as the need for the development of associative strategic planning and the creation of incentives for its management as an intelligent or innovative tourism destination.

The raising of basic information by the application of empirical techniques and tools reflects the relevance of tourism activity for the development of the study territory.

However, the surveyed tourists, expressed a low perception of the technological management before, during and after their visit and a low investment in projects and applications related to $\mathrm{R}+\mathrm{D}+\mathrm{i}$. Based on the study and previous practices of internationally recognized references such as the Bogota Manual (Jaramillo, Lugones \& Salazar 2001), the Oslo Manual (RICyT, 1997; OECD, 2005) The Operational Manual for the Configuration of STD (Agencia Valenciana del Turisme [Invat.Tur], 2015) the White Paper for Smart Tourism Destinations the White Paper for STD (Blanco, 2015) and the "Tourism 
destinations report: building the future" (López-de-Ávila et al., 2015), 19 indicators were obtained (impact, expenses, dissemination) associated with the evaluation of TI in Puerto López, which integrate public, private and community actors, in the dimensions of product, process, organization and marketing. This proposal for evaluation contributes to the planning of TI improvement processes in contact with tourists prior to the visit, during their experience and afterwards, since it becomes the starting point of future research of the subject in this tourism destination. The application of the Kendall method with the Chi Square test, as validation instruments of the proposed indicators, reported that there is no accidental coincidence among experts, so it is concluded that the consistency between their opinions is strong, in relation to the proposed system for the evaluation of the TI in Puerto López. For this reason, based on the application of the validation instrument used, it is confirmed that the main indicators are: Certifications / recognitions on products and / or processes related to technological innovation; Technological innovations with R \& D; Innovative tourism activities (ITA), Programs / projects aimed at promoting ITA, Use of ICT by tourism companies and Open data (OD).

\section{REFERENCES}

Alatorre, E.A., \& Pérez, E.M. (2011). Procedure for measuring tourist demand at a destination, 4(december), 1-25.

Alfaro, C., \& Gómez, J. (2016). A system of indicators for measurement, evaluation, innovation and participation oriented to the public administration. Methaodos.revista de Ciencias Sociales, 4(2), 274-290.

Alfonso, R. (2013). Procedure for the diagnosis of the system of technological management and innovation in tourist transport entities. In Central University "Martha Abreau" de Las Villas, Las Villas, Cuba.

Alfonso, R., Rodríguez, A., \& Blanco, G. (2016). Technological management and innovation in the tourism sector and elements for the selection of strategies. In La Universidad en el Siglo XXI.

Azar, G., \& Ciabuschi, F. (2017). Organizational innovation, technological innovation, and export performance: The effects of innovation radicalness and extensiveness. International Business Review, 26 (2), 324336. doi:10.1016/j.ibusrev.2016.09.002.

Badii, M., Guillen, A., Lugo, O., \& Aguilar, J. (2014). Non-Parametric Correlation and Its Application in Scientific Research. International Journal of Good Conscience, 9 (2), 31-40.

Blanco, J. (2015). White Paper on Smart Tourist Destinations: Strategies and solutions to encourage innovation in digital tourism. Madrid, Spain.

Castillo Hernández, L., Lavín Verástegui, J., \& Pedraza Melo, N.A. (2014). The triple-helix management: strengthening relations between university, company, government. Multiciencias, 14(4), 438-446.

Cosma, S., Paun, D., Bota, M., \& Fleseriu, C. (2014). Innovation - A Useful Tool in the Rural Tourism in Romania. Procedia - Social and Behavioral Sciences, 148, 507-515. https://doi.org/10.1016/j.sbspro.2014.07.073

Damanpour, F., Walker, R. M., \& Avellaneda, C.N. (2009). Combinative effects of innovation types and organizational performance: A longitudinal study of service organizations. Journal of Management Studies, 46, 650-675.

Decelle, X. (2004). A conceptual and dynamic approach to innovation in tourism. Innovation and Growth in Tourism, 16p. https://doi.org/10.1787/9789264025028-7-en.

Dewangan, V. \& Godse, M. (2014). Towards a holistic enterprise innovation performance measurement system. Technovation 34 (9), 536-545.

Diaconu, M. (2011). Technological Innovation: Concept, Process, Typology and Implications in the Economy. Theoretical and Applied Economics, 18(10), 127-144.

Dziallas, M. \& Blind, K. (2019). Innovation indicators throughout the innovation process: An extensive literature analysis. Technovation. 80-81. pp: 3-29. https://doi.org/10.1016/j.technovation.2018.05.005.

Erspective, L.O.P., \& Lusch, R.F. (2015). Service Innovation: A Service-Dominant-Logic perspective. MIS Quarterly, 39(1), 155-175. https://doi.org/10.25300/MISQ/2015/39.1.07

García, N., Carreño, Á.L., \& Doumet, N.Y. (2016). Strategies for tourism development of Canton Bolivar post earthquake April 16 (Ecuador). ECA Sinergia, 7(2), 26-39.

Garcia, N., Doumet, Y., \& Carreño, L. (2018). Post-earthquake strategic tourism plan for the municipality of Bolívar, Manabí, Ecuador. GeoJournal of Tourism and Geosites, 23(3), 881-894. https://doi.org/10.30892/gtg.23322-336

Garcia, R., \& Calantone, R. (2002). A critical look at technological innovation typology and innovativeness terminology: a literature review. Journal of Product Innovation Management, 19 (2), 110-132. doi:10.1111/1540-5885.1920110.

Gault, F. (2018). Defining and measuring innovation in all sectors of the economy. Research Policy Journal. 47 (3), pp 617-622, DOI: https://doi.org/10.1016/j.respol.2018.01.007. 
Design of an Indicators System for the Evaluation of Technological

Innovation in the Tourism Destination of Puerto Lopez, Ecuador

Goffin, K. \& Mitchell, R. (2017). Innovation Management: Effective Strategy and Implementation. Third Edition. London: Palgrave. Macmillan Education.

Jaramillo, H., Lugones, G. \& Salazar, M. (2001). Indicators standardization for technological innovation in Latin America and the Caribbean, Manual of Bogota. Ibero-American Network of Science and Technology Indicators (RICyT), Organization of American States (OAS) \& CYTED Program. Retrived from: http://www.ricyt.org/manuales/doc_view/5-manual-de-bogota [Accessed: May 12, 2019].

Hernández, L. (2013). Improvement plan for the Technological Management and Innovation activity at the Cubatur Villa Clara Travel Agency. Central University "Marta Abreu” de las Villas.

Hjalager, A.M. (2010). A review of innovation research in tourism. Tourism Management, 31(1), 1-12. https://doi.org/10.1016/j.tourman.2009.08.012.

Kogan, L., Papanikolaou, D., Seru, A., \& Stoffman, N. (2017). Technological innovation, resource allocation, and growth. Quarterly Journal of Economics, 132(2), 665-712. https://doi.org/10.1093/qje/qjwo40.

López-de-Ávila, A., Lancis, E., García, S., Alcantud, A., García, B., \& Muñoz, N. (2015). Tourism destinations report: building the future. Segittur. https://doi.org/10.1007/s13398-014-0173-7.

Márquez, C. \& Márquez, M. (2018). Study of sustainable rural development in the Baba canton of Ecuador using multivariate methods. Investigación Operacional, 39 (2), 250-254.

Meiriño, R.C., Fraiz, J.A., Vila, N.A., \& Lopez, E.R. (2016). Segmentation of the market of domestic tourism destination. The case of A Ribeira Sacra (Ourense). PASOS. Journal of tourism and cultural heritage, 14(2), 369-383.

Mohd, N., Abd, S., Al-Mamun, A., Sofian, A., Kumar, N. \& Ali, S. (2016). Defining the concept of innovation and firm innovativeness: A critical analysis from resorce-based view perspective. International Journal of Business and Management, 11 (6). pp. 87-94. DOI: 10.5539/ijbm.v11n6p87.

Pisano, G.P. (2015). You need an innovation strategy. Harvard Business Review.

Ponti, F. (2013). The 7 movements of innovation. (Norma S.A., Ed.) (2nd ed.). Bogotá, Colombia.

Reinoso, N.G., Doumet, Y.N., \& Alfonso, R. (2019). Territorial impact of the earthquake to the tourist sector of the Bolívar canton, Ecuador. Revista Turismo - Visão e Ação, 21(1), 42-64. https://doi.org/10.14210/ RTVA.V21N1.P42-64

Ríos, H., y Marroquín, J. (2013). Technological innovation as a mechanism to boost economic growth. Regional evidence for Mexico. Revista Contaduría y Administración 58 (3), 11-37

Rivas, F. (2006). Innovación y Tecnología. Visión Gerencial, (1), 2. http://www.redalyc.org/articulo.oa?id=465545874001.

Simpson, P.M., Siguaw, J.A., \& Enz, C.A. (2006). Innovation orientation outcomes: The good and the bad. Journal of Business Research, 59(10-11), 1133-1141. https://doi.org/10.1016/j.jbusres.2006.08.001

Souto, J.E. (2015). Business model innovation and business concept innovation as the context of incremental innovation and radical innovation. Tourism Management, 51, 142-155. https://doi.org/10.1016 /j.tourman.2015.05.017

Suárez, R.P. (2018). Reflections on the concept of innovation. Revista San Gregorio, (24), 120-131. Recuperado de: http://revista.sangregorio.edu.ec/index.php/REVISTASANGREGORIO/article/view/575/14-ROGELIO.

Taylor, S.P. (2017). What Is Innovation? A Study of the Definitions, Academic Models and Applicability of Innovation to an Example of Social Housing in England. Open Journal of Social Sciences, 5, 128-146. https://doi.org/10.4236/jss.2017.511010.

Thomas, R., \& Wood, E. (2014). Innovation in tourism: Re-conceptualising and measuring the absorptive capacity of the hotel sector. Tourism Management, 45, 39-48. https://doi.org/10.1016/j.tourman.2014.03.012

*** Agencia Valenciana del Turisme (Invat.Tur). (2015). Smart tourism destinations: Operative Manual for the Configuration of Smart Tourism Destinations. Valencia, España. https://doi.org/10.1007/s13398-014-0173-7.2

*** GAD Puerto López. (Decentralized Autonomous Government of the canton of Bolívar) (2015). Spatial and Territorial Development Plan, Municipality of Puerto López, 2015. Retrieved from http://app.sni.gob.ec/sni-link/sni/PORTAL_SNI/data_sigad_plus/sigadplusdocumentofinal/1360003 300001_PDYOT_PUERTO_LOPEZ_2014_2019_14-04-2015_20-35-13.pdf

*** INEC. (National Institute of Statistics and Census of Ecuador) (2010). Population and Demography . Retrieved October 26, 2018, from http://www.ecuadorencifras.gob.ec/censo-de-poblacion-y-vivienda/

*** OECD. (Organisation for Economic Co-operation and Development) (2005). The Measurement of Scientific and Technological Activities, Oslo Manual: Guidelines for collecting and interpreting innovation data. Oslo Manual. Retrieved from http://www.oecd.org/science/inno/2367614.pdf [Accessed May 12, 2019],

*** Redes. (1996). Technological innovation: Definitions and base elements. 3 (6), 131-175.

*** RICyT. (Ibero-American Network of Science and Technology Indicators) (1997). Oslo Manual - Context, Projections. Third Iberoamerican / Interamerican conference procedure on science and technology indicators.

*** SENPLADES. (National Secretary for Planning and Development of Ecuador) (2013). National Plan for the Good Living of Ecuador 2013- 2017: Everybody is better. (C. N. de Planificación, Ed.) (2nd ed.). Quito: Republic of Ecuador.

*** UNWTO. (World Tourism Organization) (2018). World Tourism Day focuses on innovation and digital transformation | WTO World Tourism Organization. Retrieved October 1, 2018, from http://www2.unwto.org/es/pressrelease/2018-07-18/el-dia-mundial-del-turismo-se-centra-en-la-innovacion-y-la-transformacion-d

Submitted:

07.03.2018
Revised:

05.07.2019
Accepted and published online

29.07.2019 